\title{
COMMUNITY BASED ECOTOURISM STRATEGIES: KEY INDICATORS FOR SUCCESSFUL PRACTICES IN DEVELOPING COUNTRIES
}

\author{
M. M. ELBARMELGY \\ Professor at The Urban Planning \\ Program, Architecture \\ Department at Faculty of \\ Engineering - Cairo University \\ Dr.barmelgy@gmail.com
}

\author{
S. A. GAMMAZ \\ Assistant Prof, Department of \\ Architecture, Faculty of \\ Engineering, Cairo University \\ sheringammaz@eng1.cu.edu.eg
}

\author{
M. S. EMARA \\ A PHD researcher in Architectural \\ Engineering Department at Faculty \\ of Engineering - Cairo University \\ marwaa.salah@yahoo.com
}

\begin{abstract}
Community-Based Ecotourism Development (CBE) strategy is considered the logical link between the environment, local community, and tourism industry. It emphasizes on locals' support and the fact that encouragement and motivation are the only ways to attain the protection of the environment and the enhancement of tourism development. Ecotourism practices in many countries faced various obstacles that hinder their success such as lack of training, services, infrastructure, and marketing budget. Therefore, The CBE strategies have been formulated by some developing countries to fill in these gaps. These governments have actually succeeded in the implementation of those strategies, and it showed a positive impact on economic development, environmental management, and local community empowerment. Therefore, the purpose of this paper is to examine the characteristics of successful community-based ecotourism initiatives and identify the principles of a successful CBE development strategy and its indicators, by analyzing the different implemented strategies in those developing countries, using the analytical and comparative approach. The paper focused on four developing countries, which are: Kenya, Jordan, Tunisia, and India, in addition to their strategic locations and their unique ecological characteristics, the case studies were selected also based on their followed successful techniques in facing their economic, social, political, and ecological problems and challenges. The paper concludes the methods used to measure the success of these strategies by identifying several and varied indicators that should be taken into account to ensure their effectiveness and sustainability.
\end{abstract}

Keywords: community based ecotourism, developing countries, local community, successful strategy, development indicators, Egypt.

\section{INTRODUCTION}

The strategic location for many developing countries with its rich biodiversity and ecosystem made tourism among the rapidly growing industries. Unfortunately, the poor management of this industry in most developing countries is one of the major causes of destroying the environmental and natural resources, changing community characteristics and traditions as well. Besides, most of the Third World governments prefer to get the maximum benefits of its ecotourism resources by boosting foreign investments and attracting international tourists, rather than empowering the local communities or supporting them to be involved in this sector (Telfer and Sharpley, 2008). Too often, these developments had led to a country's dependence on foreign products and foreign investment skills. Due to the existing strategies that grant the national governments in these developing countries the upper hand in decision making process while not allowing the other stakeholders both regional and local to be involved, thus generally failed to bring about sustainable development, and many negative consequences on the local development and the natural 
environment arise (Tamagn, 2015), (Fennell D. A., 2014). The lack of effective community participation in the planning process always results in plans that rarely meet the locals' needs or interests and excludes the local businesses, which in turn may lead to unfavorable socio economic costs, for example: spreading vandalism, theft, lack of sense of belonging and careless damage (Ibrahim, 2011). Furthermore, the preparation of several development plans with different land uses proposals for the same area, as a result of the conflict between the national governmental authorities themselves, consequently that lead to the loss of the desired goals for the local area development. Along with the conflict between the interest of the tourism sector and the local resources and land use practices (IOM, 2012). Therefore, the challenge of sustainable tourism development on one hand is to avoid the negative impacts and the degradation of resources, and on the other hand channel the benefits into the right direction (ETE, 2009). In response to these negative impacts, a new form called Community Based Ecotourism (CBE) has appeared and became a promising environmental and social development alternative (Loughlin, 2012). CBE strategy is the type of ecotourism strategies that will maximize benefits and minimize harm to local communities in the future, through promoting jobs, new business opportunities, and skills development. Its strategy has a pivotal role to play in setting and enforcing regulations that protect natural and cultural areas, while also providing mechanisms to support local involvement in ecotourism process and management (MPIC, 2012), (EEAA \& MSEA, 2010).

Every developing country needs to prepare a proper CBE strategy, without it, the benefits cannot be equally distributed among the local community and other relevant stakeholders and the adverse impacts of tourism will increase (CISS \& EDG, 2012), (Katia lankova, 2016). The main purpose of preparing CBE strategies in the developing countries is to strengthen relations between the local community and the relevant stakeholders to draw plans that meet their needs and expectations, this will affect positively on the society, environment and the economy (EEAA, 2017), (Shalaby, 2012), (Hegazy, 2010). It mainly accounts on engaging community during the preparation of tourism development strategies process, through having the honest stakeholders with the required skills, legitimate power and experience of being unbiased during making decisions and suggestion of solutions (Ibrahim , 2011), (IOM, 2012).

Currently, there are enormous efforts, time and funds that are used in promoting the CBE strategies and plans in some of those countries; nevertheless, some succeed while others fail to improve the social, economic or environmental well-being. Hence, it is important to identify the key structural indicators of the successful CBE strategy which ensure the local community involvement in the development process and decision-making. This paper aims to explore the key indicators, which are essential tools for measuring the effectiveness of CBE strategy implementation, through the analysis of strategies that have been successfully applied in developing countries, using the comparative analysis method. To achieve this objective, the paper was divided into four sections: section one, gives a brief overview on the major component and principles of successful CBE strategies and the roles of relevant 
stakeholders based upon the review of the relevant literature. Section two, four case studies of successful CBE strategies in developing countries are analyzed. Section three, a comparison among the four CBE strategies of the developing countries shows how they succeeded in solving the economic, social, environmental and political problems. Section four, discussions and conclusions are drawn in the final section to identify the core indicators for measuring the effectiveness of CBE strategies in developing countries.

\section{COMMUNITY-BASED ECOTOURISM (CBE) STRATEGIES}

Ecotourism managed by the community is a popular model, emerged in the mid-1990s through a combination of progressive actions by governments, donors, non-governmental organizations, tourism companies, and communities themselves, it called "Community Based Ecotourism (CBE) " (Brohman, 1996). The CBE concept mainly appears due to the necessity of increasing the level of local community participation in the development and practice of its projects, sharing benefits with the whole community, and accessing to natural resources that can be used to attract ecotourism (Leksakundilok, 2004). Many authors and organizations agreed that CBE strategy on one hand should emphasize the development of local communities and allows for local residents to have substantial control over, and involvement in, its development and management, and have a major share of its benefits. On the other hand Community-based ecotourism should foster sustainable use of resources and enforce regulations to protect natural and cultural areas through collective responsibility (WWF, 2001), (Cusack \& Dixon, 2006), (Ashley, C., Roe, D. and Goodwin, H., 2001), (Thammajinda, 2013).

Some governments of the developing countries have promoted CBE as part of their national development plans for poverty alleviation. Furthermore, major donors have assisted CBE product, organizational and program development, and include the European Union (EU), Netherlands Development Organization (SNV), United States Agency for International Development (USAID), World Wildlife Fund International (WWF), United Nations Development Programme Global Environment Facility - Small Grants Programme (UNDP GEFSGP) and the United Nations Educational, Scientific and Cultural Organization (UNESCO). Therefore, many strategies are enacted to support community involvement within all levels of the CBE process, including ways to regulate ecotourism development plans, marketing and facilitate community training for small and medium-sized enterprises management; this refers to the process of creating long-term conformity between managerial targets and changing market opportunities. All practices and operations related to Ecotourism must be done on the basis of a strategic plan. It helps the governments to recognize strengths, weaknesses, opportunities, and threats and apply these findings for improving and enhancing the benefits of the tourism industry. Therefore, governments can gain a competitive advantage by preparing strategies which are applicable in the market (Salazar, 2012), (NCS, 2006), ( The green economy in Tunisia, 2014). Many organizations have reported the major principles of CBE to ensure its sustainability and applicability, and this can be summarized as follows: 
1-Ensure an appropriate institutional framework, an efficient structure with defining clear roles for the public and private sectors is a precondition for the administration the CBE development. Therefore, making the list of stakeholders and their functions must be a priority, where Local leadership leads plans and encourages clear and transparent decisionmaking. Also, all relevant stakeholders need to be trained and equipped with the tools and knowledge necessary for decision-making (UNEP, WTO, 2005).

2- Strengthen the environmental regulations for managing the natural and protected areas, ecotourism resources must be managed in a sustainable way to ensure their long-term capability and continuity. These regulations should be concerned with planning and managing activities in the natural sites a way that ensures visitor satisfaction, protecting the fragile natural sites and its biodiversity, waste management, and controlling the use intensity; while highlighting the unique aspects of the locality, such as topography, climate, natural elements and protected areas. Only through coordinated planning and management will these unique assets be protected for the current and future generations (OECD, 2010).

3-Ensure safety, security and easy access, through providing the adequate and efficient modes of traveling, simple and stress-free entry and/or departure facilities. The Strategy comes to ensure that the country is safe and hospitable and ready to perceive tourists, also, to minimize the adverse publicity arising from the high incidence of accidents involving tourists, by improving the infrastructure and road safety (TDA, 2008).

4-Expand the product base, expanding and developing new products, and diversifying the geographical distribution of it, besides, highlighting local cultural practices so that communities share their cultures and traditions with tourists with authenticity (OECD, 2010).

5-Human resources training and personal development, skills, expertise, and positive attitudes are essential for ecotourism success. The lack of skilled people acts as a major constraint on the industry's ability to achieve optimum growth and present a high-quality service. A priority policy is to improve skills to work in ecotourism development projects. The capacity of training institutions should be expanded to be able to cope with market demands. And, Support both men and women involved in ecotourism development plans to provide a high quality of services that meet the requirements of both community and tourists (UNWTO, 2013).

6- Provide the necessary infrastructure and superstructure, the strategy should include the development of an adequate transport infrastructure and utility networks to support superstructure in a sustainable way, aiming to the self-sufficiency in energy and water (TDA, 2008).

7- Improve the quality of service, a key element of the strategy is to ensure that the sector can attract, recruit and train/retain the human capital to develop in line with the Strategic Plan. It also can improve the quality of activities and ensure that services can meet the demands of international visitors (UNEP, WTO, 2005). 
8- Promote the local product to the markets, the strategy argues to support Small and medium-sized enterprises (SMEs) both as important suppliers indirectly contributing to the overall ecotourism product and as producers who benefit from the development of ecotourism. It is essential to keep this advantage by ensuring mechanisms facilitating and encouraging competition in the international marketplace with rival destinations (TDA, 2008).

9- Respect and preserve the identity, This is the key to uniqueness and exclusivity in global competition, CBE strategy should help the community reclaim historical practices, revitalize productive activities and highlight the ethnic background of the population. Recalling the roots of the locality with its unique characteristics for instance in architecture, cuisine, music and handicrafts, (UNWTO, 2013).

In conclusion, there are important guiding principles (as shown in figure.1) that CBE strategy should focus on, and they are:

Fig (1) the guiding principles of the CBE Strategy, Author based on: (TDA, 2008), (UNWTO, 2013).

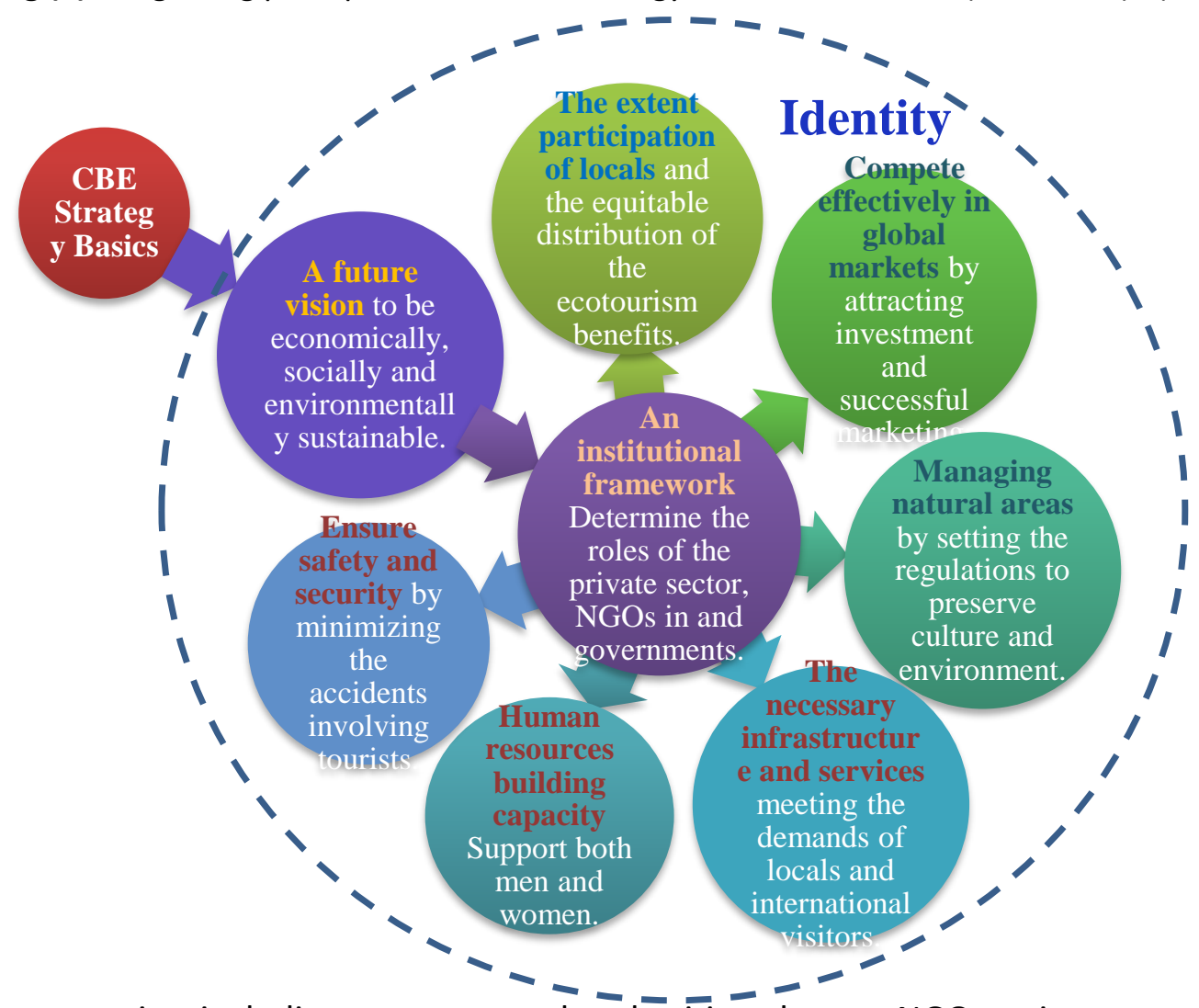

Many agencies, including governmental authōities, donors, NGOs, private sector interests, and community representatives are actively involved in ecotourism initiatives adjoining protected and natural areas. (Asker, 2010), gives us a conclusion of different ways to support CBE by ecotourism stakeholders (as shown in figure.2): 
Fig (2) Relevant stakeholders of the CBE Strategy, based on: (Asker, 2010)

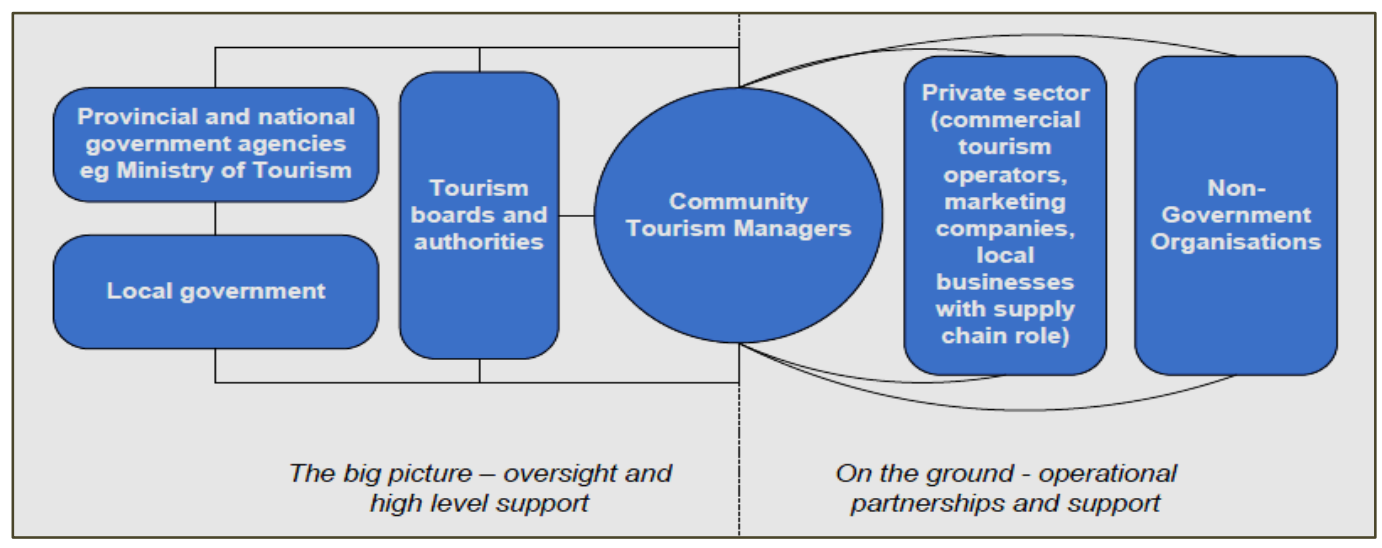

\section{THE INTRODUCTION OF CBE CASE STUDIES}

In order to analyze and evaluate the various CBE strategies within the developing countries, this study seeks to deal with the subsequent queries, and these queries are: what were the barriers that hinder CBE strategy implementation? How stakeholders did manage the human and natural resources? finally, what are the indicators of success or failure the CBE strategy implementation? Four CBE strategies are selected in this paper as case studies which are Kenya, Jordon, Tunisia, and India. They're designated for several reasons: the strategic location of the destination, the distinctive ecological characteristics, the unique nature, the link with the local culture and communities, and the most significant reason is its success and positive impact on their communities and economy. These countries also have been selected specifically based on different criteria such as social, economic, environmental and political criteria, as follows (EK, 2016), (El-Harami, 2014), (Baken, 2010):

\subsection{Community-based ecotourism (CBE) Kenya}

Kenya is the best practice in Africa according to the evaluations of the MEET partnership, the Kenyan government's development plan wanted to shift the focus of tourism from mass tourists to upmarket eco-tourists, as well as encouraging the involvement of local entrepreneurs. Managers of protected areas in Kenya have instituted specific programs to facilitate the development of these individuals living on lands encompassing parks and reserves, for instance, some cultivation, timber harvest, and pastoralism are not absolutely allowed in areas selected, in order that local communities will meet their subsistence desires (as shown in figure.3).

Fig (3) Kenya Ecotourism attractions, (EK, 2016)

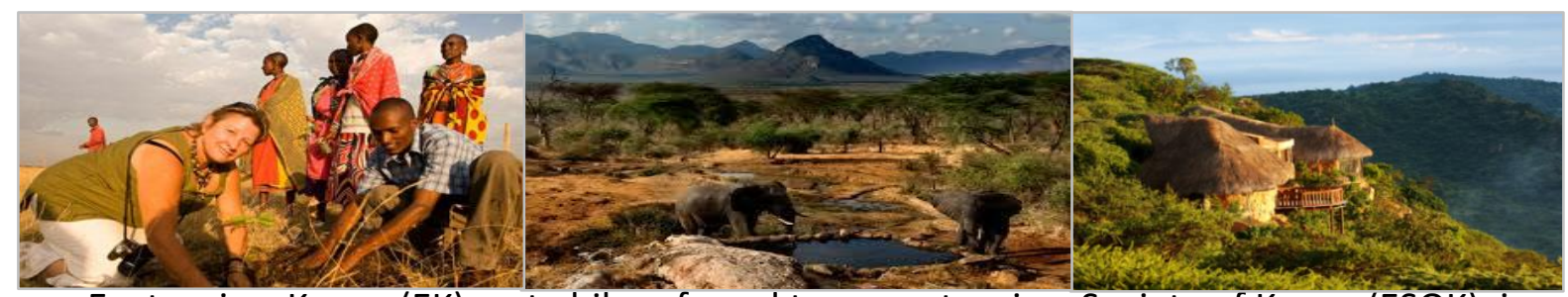

Ecotourism Kenya (EK) erstwhile referred to as ecotourism Society of Kenya (ESOK), is a civil society organization that was established in 1996. Founded with huge support from 
the tourism industry in Kenya, it plays a key role in guaranteeing that Kenya's tourism is sustainable, both in terms of concern for the environment and for the welfare of local communities. Ecotourism Kenya brings along people, Community based Organizations (CBOs) and tourism businesses in a forum where they discuss the concept of ecotourism and use the resultant information to enhance their operations towards best practices. Furthermore, it presently features a membership of roughly 550 individuals, companies, community-based organizations (as shown in figure.4). These members hold an Annual General Meeting (AGM) once every year and elect a Management Board that takes up the role of an executive Committee mandated with the task of providing overall strategic steering together with approving plans and budgets (EK, 2016), ( Ngunyi, 2009).

Fig (4) Number of people visiting natural areas from the year 1997 to 2004 (Ngunyi, 2009)

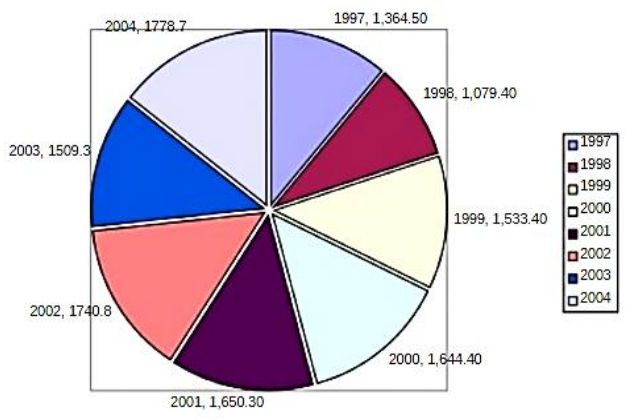

Fig.4 show the total number of people visiting some of the National Parks and Reserves in Kenya for a period ranging from 1997 to 2004. There is clear evidence that the number of people visiting the parks in Kenya has been increasing annually from 1,079,400 in 1999 to $1,778,700$ in year 2004. This can be associated with more awareness and promotion of eco based tourism in Kenya

\subsection{The Royal Society for the Conservation of Nature (RSCN) Jordan}

Jordan is considered the first country within the Middle East that place an ecotourism strategy. It's the most effective case to point out how all stakeholders operating along on a particular framework and the way advantages are distributed equally. That made its economy stronger and earned from ecotourism projects a multi-million dollar. Most of the ecotourism financial gain is employed to develop the natural and protected areas and its communities (as shown in figure.5), (RSCN, 2012).

Fig (5) Ecotourism attractions in Jordan, (RSCN, 2012)

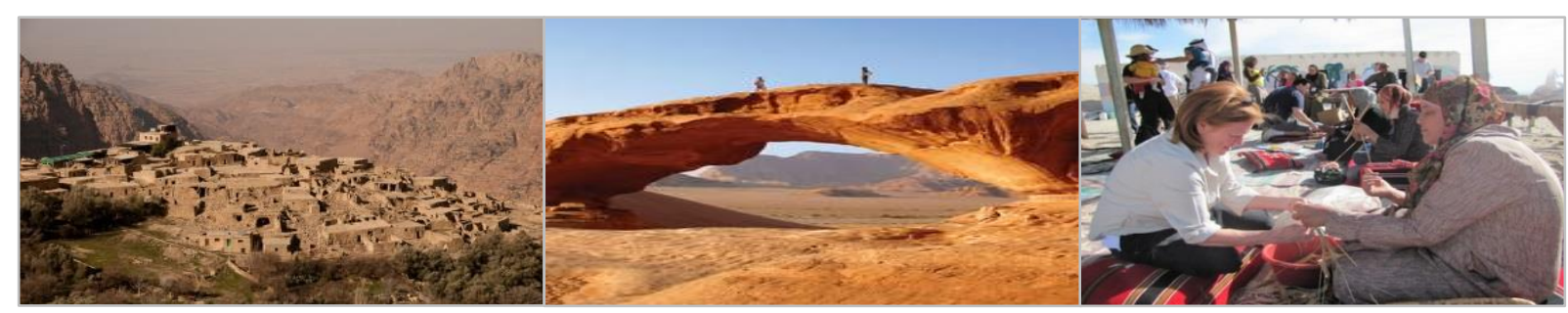

The early history of ecotourism in Jordan is attributed to King Hussein who was behind the creation of the Royal Society for the Conservation of Nature (RSCN) in 1966, which is a non-government organization dedicated to the conservation of Jordan's natural surroundings. It has been entrusted by the government with the protection and management of Jordan's special ecosystems (RSCN, 2012). At the start and for many years, RSCN managed its protected areas for decades as isolated sanctuaries, enclosed and 
guarded from the general public, with very little involvement of local communities. This all modified in 1992 with the Rio Summit and the Biodiversity Convention, a team of over 180 Jordanian specialists completed a practical and comprehensive operating document entitled National environment Strategy for Jordan. After that, RSCN's team developed for the organization that extends from 2015 to 2020. Consequently, the international tourist arrivals are increasing rapidly (as shown in figure.6). As a signatory of the Convention, Jordan was the primary country within the Middle East to be awarded a multi-million dollar pilot project underneath the Global Environment Facility (GEF) to develop a regional model of integrated conservation and development (El-Harami, 2014).

Fig (6) International Arrivals and Receipts - (El-Harami, 2014)

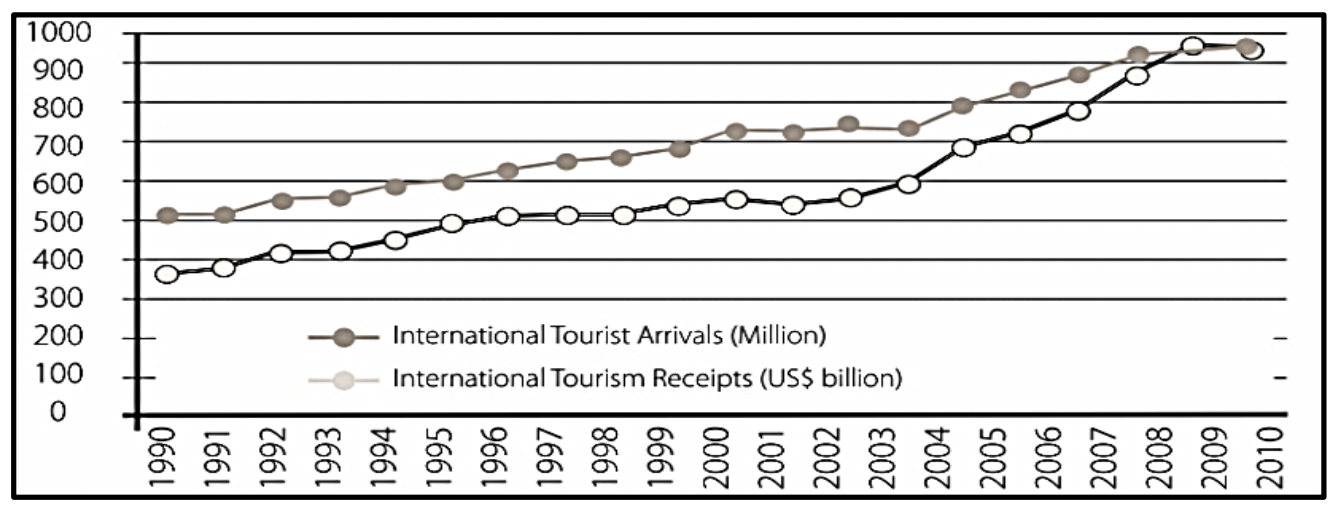

\subsection{Tunisian's National CBE Strategy}

After the Tunisian Revolution that passed in 2011, Tunisia faced a giant challenge to boost the tourism sector. It is the most effective case to point out how Tunisians are recovering through a suitable strategy that ensures safety for tourists, quality of services, and with conservation of Ecotourism attractions of natural and biodiversity sites (as shown in figure.7)

Fig (7) Ecotourism attractions in Tunisia, (The green economy in Tunisia, 2014)
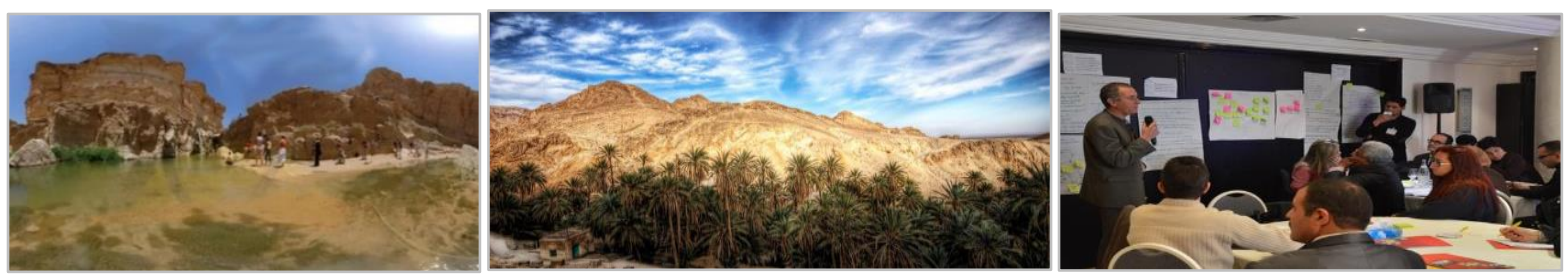

CBE and Conservation strategy for Tunisia permits higher participation by local communities and stakeholders within the management of sites and natural resources while strengthens values of local capability and ambitions (Crotti,Misrahi, 2015), this attracted more Eco-tourists to visit Tunisia (as shown in figure.8). It additionally contributes to the local economies, through operating with the young project managers, who are the future local guides. It is important to see how they have assimilated the thought of the project, developed it at the local level and reworked it at every step. Another vital aspect is definitely 
the creation of the local site management support committees for each of the sites. The committees comprise all site stakeholders which proved to be great tools for the regular exchange of knowledge and consultation around the sites. This doesn't mean that there are not any additional issues, but at least these are discussed to search out solutions together. The strategy additionally has specifically developed different kinds of training for the local nonprofits. This coaching program includes training in several topics like project management, development of projects and fundraising, biodiversity monitoring protocols, load capability and assessment of impacts, conflict management, development of ecotourism, and promotion and marketing activities (CEPF, 2016).

Fig (8) Tunisia Eco-tourists arrivals (Crotti,Misrahi, 2015)

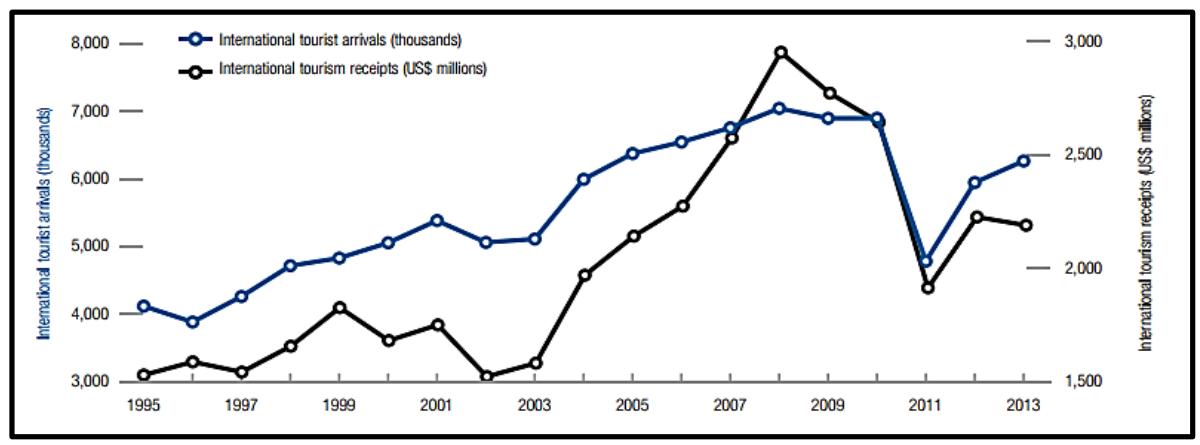

\subsection{Community Based Ecotourism (CBE) in India}

India is considered one of the foremost numerous tourer countries within the world; it has plenty of cultural and natural potentials that make tourism the second largest economic sector (as shown in figure.9). The priority in its strategy is how to conserve the natural areas and also the local's culture during the tourism development process (Gopal, 2012).

Fig (9) Ecotourism attractions in India, (Gopal, 2012)

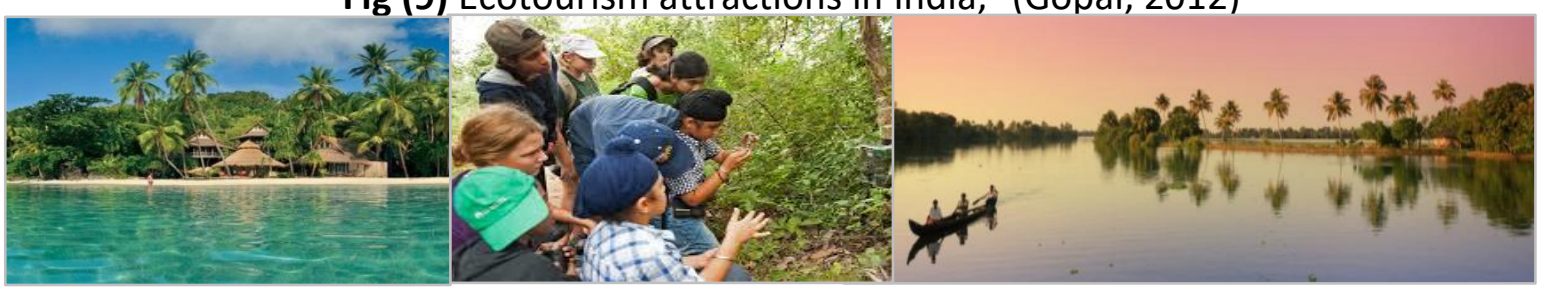

In the two decades between the first and the second Rio Summits of 1992 and 2012 respectively, the world has seen a plethora of national strategies for sustainable development. Ecotourism that is community driven and conservation-focused was indeed a part of this international wave, it engulfed India too. India's international CBE industry is growing rapidly, to promote sustainable travel, protect the environment and ensure eco-tourist dollars are supporting locals, the government of India is actively promoting community-based ecotourism (Baken, 2010). As a result, the FTA (foreign tourist arrivals) jumped to six million in 2010 from 2.5 million in 1997. The globe touristy Organization is quite confident that India is going to be hosting nearly ten million by 2020 . In 2011 the government made 26.7 billion USD worth of investments within the sector, 
the second highest in Asia (as shown in figure.8). A very important incentive and support for ecotourism and communities in India are from UN agencies like the UNEP and UNDP (Crotti,Misrahi, 2015).

Fig (10) showing the total spending of eco-tourists in the economy

Eco-tourists arrivals, (Crotti,Misrahi, 2015),

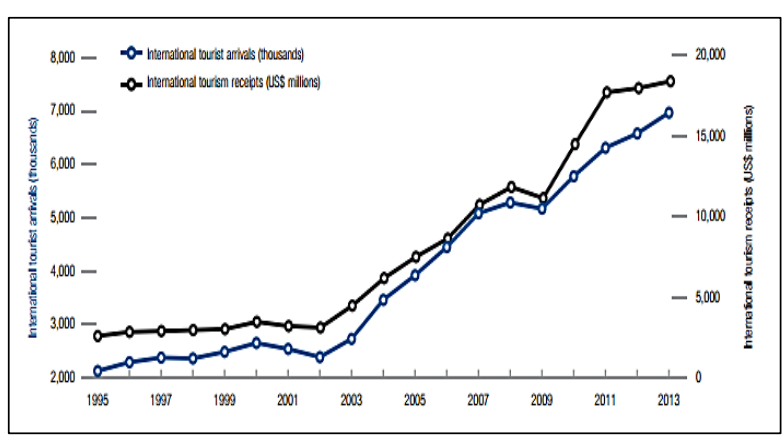

\begin{tabular}{||l|l|l|l|}
\hline Years & $\begin{array}{l}\text { Total International Tourism } \\
\text { Arrivals }\end{array}$ & Nature Tourists & $\begin{array}{l}\text { Wildlife-related } \\
\text { Tourists }\end{array}$ \\
\hline 1988 & 393 million & $157-236$ million & $79-157$ million \\
\hline 1994 & 528.4 million & $211-317$ million & $106-211$ million \\
\hline
\end{tabular}

Table showing number of eco-tourists

in the total international tourist arrivals

\begin{tabular}{||l|l|l|l|}
\hline Years & $\begin{array}{l}\text { Total International Direct } \\
\text { Economic Impact * }\end{array}$ & $\begin{array}{l}\text { Nature Tourists } \\
\text { Wildlife }\end{array}$ & Related Tourists \\
\hline 1988 & US\$388 billion & US\$93-223 billion & US\$47-155 billion \\
\hline 1994 & US\$416 billion & US\$166-250 billion & US\$83-166 billion \\
\hline \multicolumn{2}{|l|}{$\begin{array}{l}\text { * Total International Direct Economic Impact } \\
\text { abroad money spent on travel by tourists traveling }\end{array}$} \\
\hline
\end{tabular}

\section{METHODOLOGY}

The paper was designed to identify the indicators of success of CBE strategies in developing countries who succeeded in implementing the CBE strategy despite the challenges and obstacles they long-faced. This was done through a theoretical study for four case studies using the comparative analytical approach. Data were collected through published books, governmental and non-governmental reports, researches, educational journals, and monographs. The collected data embody the factors of strengths, weakness, opportunities, and threats of implementing a CBE strategy within the developing countries.

\subsection{The Survey Limitations:}

The author faced many barriers in collecting data as field surveys were not possible, besides the information from the previous studies and reports were not enough to describe and measure the changes after the implementation of CBE development plans.

\section{CBE STRATEGIES IN DEVELOPING COUNTRIES}

Many developing countries nowadays are interested in CBE strategies, to ensure sustainable tourism, besides the conservation of the environment and the welfare of local communities, these countries like Kenya, Jordan, Tunisia, and India. The strategies of these developing countries came to support the economic sector of tourism through protecting the surroundings and empowering local communities, to ensure its success and sustainability. Each strategy faced several challenges in every level of the process, (as shown in Table.1), for example: in Kenya, the legal hunting and poaching had a significant negative impact on the survival of the rare species; therefore, the government had banned hunting with severe penalties. For solving this problem that seemed to threaten the success of ecotourism efforts, 
the government launched an enormous promotional campaign "Come shooting in Kenya with your camera" that specialize in natural and wildlife resources, in addition to, a touristic consultative Committee was established to discuss the related issues and find solutions frequently. In Jordan, the involvement of local communities in nature reserves development makes ecotourism a rapidly growing market in the country, it reduces poverty, protects the environment and restores heritage. To apply ecotourism plans successfully, Jordan started training skilled guides who have superb information about Jordan's ecology. Now Jordan is considered a pioneer in ecotourism as illustrated within the number of nature reserves unfolded in varied distinctive locations that embody mountains, forests, similarly as deserts. In Tunisia, abundant of ecotourism resources remains developing within the wake of the Tunisian Revolution that materialized from 2010 to 2011. To increase the revenue from international eco-tourists, Tunisia has been developing ecotourism activities for the conservation of key biodiversity areas, conjointly supporting local communities to manage the most necessary natural areas in it. These sites are organized as a network, with each of them taking advantage of support to rehabilitate tourism infrastructure and train guides. At last, in India, ecotourism was meant to conserve and demarcate habitats and species. It conjointly meant to shield the interests of the marginalized communities just like the tribal in India. The following table can review how CBE strategies succeeded in handling the economic, social, and therefore the ecological issues and challenges at these countries (Gopal, 2012), (Bhanoo, 2015), (EEAA \& MSEA, 2010), (RSCN, 2012):

Table (1) Comparison among the CBE strategies in the developing countries, Author based on: (Gopal, 2012), (Bhanoo, 2015), (EEAA \& MSEA, 2010), (RSCN, 2012).

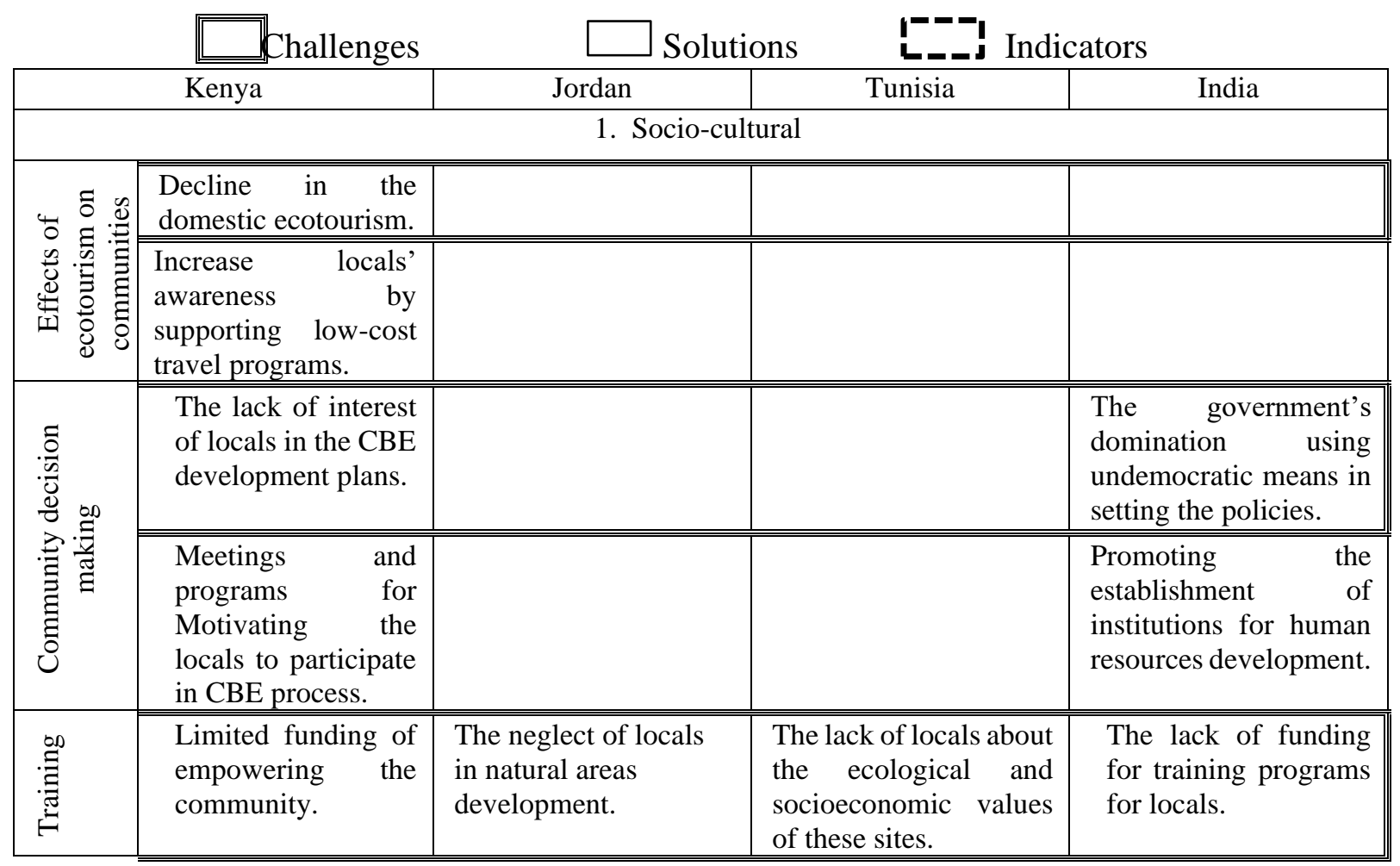




\begin{tabular}{|c|c|c|c|c|}
\hline & $\begin{array}{l}\text { Develop a budget } \\
\text { plan for training } \\
\text { programs for the } \\
\text { locals. }\end{array}$ & $\begin{array}{l}\text { Promoting the local } \\
\text { awareness } \\
\text { participate in } \\
\text { programs. }\end{array}$ & $\begin{array}{l}\text { Different training } \\
\text { programs such as } \\
\text { project management, } \\
\text { fund-raising, } \\
\text { biodiversity } \\
\text { monitoring, and } \\
\text { marketing activities. }\end{array}$ & $\begin{array}{l}\text { An incentivized and } \\
\text { support for ecotourism } \\
\text { and communities } \\
\text { training in India by the } \\
\text { UN agencies like the } \\
\text { UNEP and UNDP. }\end{array}$ \\
\hline \multirow[b]{2}{*}{ 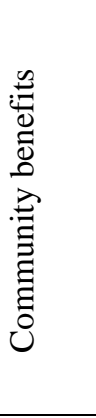 } & $\begin{array}{l}\text { The inequitable } \\
\text { distribution of } \\
\text { ecotourism benefits. }\end{array}$ & $\begin{array}{l}\text { The conflicts between } \\
\text { the local entrepreneurs } \\
\text { inside protected areas. }\end{array}$ & & $\begin{array}{l}\text { Decline the income of } \\
\text { involved locals in } \\
\text { Ecotourism activities. }\end{array}$ \\
\hline & 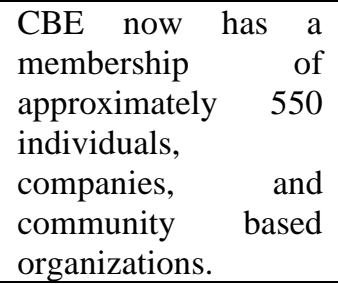 & $\begin{array}{lr}\text { Diversifying } & \text { income } \\
\text { sources for developing } \\
\text { communities } r \text { and } \\
\text { managing protected } \\
\text { areas. }\end{array}$ & & $\begin{array}{l}\text { Ecotourism operators } \\
\text { sharing its revenue } \\
\text { directly in community } \\
\text { development. }\end{array}$ \\
\hline \multirow{2}{*}{ 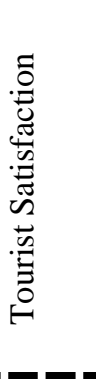 } & $\begin{array}{l}\text { The difficulty of entry } \\
\text { points and visa } \\
\text { problems. }\end{array}$ & & $\begin{array}{l}\text { Absence of security due } \\
\text { to Tunisian Revolution } \\
2011 \text { affected on } \\
\text { tourists' number. }\end{array}$ & \\
\hline & $\begin{array}{l}\text { Cooperating with the } \\
\text { tour operators, travel } \\
\text { agents, and the main } \\
\text { airlines. }\end{array}$ & & $\begin{array}{l}\text { A program of } \\
\text { improving management } \\
\text { and security system of } \\
\text { the natural sites and } \\
\text { adjacent areas. }\end{array}$ & \\
\hline 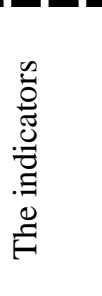 & $\begin{array}{l}\text { - Increase of public } \\
\text { awareness towards } \\
\text { sustainability. } \\
\text { - Increase of local } \\
\text { community standard } \\
\text { living. }\end{array}$ & $\begin{array}{l}\text { - Involvement of local } \\
\text { communities in the } \\
\text { process. } \\
\text { - Distribution rer of } \\
\text { product related } \\
\text { incomes to local } \\
\text { community. }\end{array}$ & $\begin{array}{l}\text { - Increase of local } \\
\text { community capacity } \\
\text { of influencing policy } \\
\text { making system. }\end{array}$ & $\begin{array}{l}\text { - Upgraded ecotourism } \\
\text { training institutes. } \\
\text { - Sharing the incomes } \\
\text { directly and equally } \\
\text { with local } \\
\text { community. }\end{array}$ \\
\hline \multirow{2}{*}{ 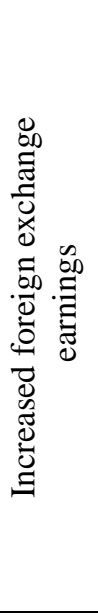 } & $\begin{array}{l}\text { The financial issues } \\
\text { (tax exemptions, } \\
\text { export promotion } \\
\text { gratuities, licensing, } \\
\text { and duty-free imports } \\
\text { of equipment ) } \\
\end{array}$ & $\begin{array}{l}\text { The lack of incentives } \\
\text { to attract investments. }\end{array}$ & $\begin{array}{l}\text { The sharp decline in the } \\
\text { national income of } \\
\text { tourism sector. }\end{array}$ & $\begin{array}{l}\text { The decrease of foreign } \\
\text { exchange earnings } \\
\text { during applying mass- } \\
\text { tourism strategies. }\end{array}$ \\
\hline & $\begin{array}{l}\text { Providing the Fiscal } \\
\text { incentives for foreign } \\
\text { investors. }\end{array}$ & $\begin{array}{l}\text { Now there are } \\
\text { agreements with over } \\
40 \text { companies for } \\
\text { bringing clients to } \\
\text { RSCN facilities. And } \\
\text { introducing several } \\
\text { innovative marketing } \\
\text { initiatives. }\end{array}$ & $\begin{array}{l}\text { Tunisia brought in more } \\
\text { than } 6 \text { percent of the } \\
\text { country's GDP in } 2013 \text {, } \\
\text { with } \$ 2.86 \text { billion in } \\
\text { revenue from } \\
\text { international visitors of } \\
\text { Ecotourism. }\end{array}$ & $\begin{array}{l}\text { The FTA (foreign } \\
\text { tourist arrivals) jumped } \\
\text { to } 6 \text { million in } 2010 \\
\text { from } 2.5 \text { million in } \\
1997 \text { In } 2011 \text { the } \\
\text { government made } \\
\text { USD26.7 billion worth } \\
\text { of investments in the } \\
\text { CBE sector. }\end{array}$ \\
\hline 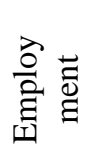 & & $\begin{array}{l}\text { Dependence on foreign } \\
\text { labor more than local. }\end{array}$ & $\begin{array}{l}\text { Marginalization } \\
\text { local workers } \\
\text { tourism sector. }\end{array}$ & \\
\hline
\end{tabular}




\begin{tabular}{|c|c|c|c|c|}
\hline & & $\begin{array}{l}\text { The employees are } \\
100 \% \text { locals; CBE } \\
\text { directly supporting } \\
\text { around } \quad 160.000 \\
\text { families throughout } \\
\text { Jordan. Through } \\
\text { income-generating of } \\
\text { CBE projects, locals } \\
\text { living around nature } \\
\text { reserves earned } 2.3 \\
\text { million USD in } 2012 .\end{array}$ & $\begin{array}{llr}\text { Working } & \text { with the } \\
\text { young } & \text { project } \\
\text { managers, } & \text { supporting } \\
\text { the local } & \text { guides in } \\
\text { CBE. } & \end{array}$ & \\
\hline \multirow{2}{*}{ 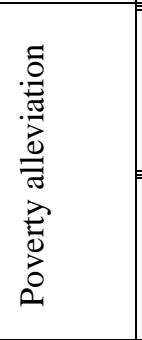 } & & $\begin{array}{l}\text { The fees of entrance } \\
\text { and activities of } \\
\text { protected areas are } \\
\text { expensive for locals. }\end{array}$ & $\begin{array}{l}\text { The lack of supporting } \\
\text { MSMEs for locals. }\end{array}$ & \\
\hline & & $\begin{array}{l}\text { Charging lower fees for } \\
\text { locals and involving the } \\
\text { privater sector }\end{array}$ & $\begin{array}{l}\text { Improve programs of } \\
\text { micro enterprises-based } \\
\text { sub-projects the locals' } \\
\text { livelihood. }\end{array}$ & \\
\hline \multirow[b]{2}{*}{ 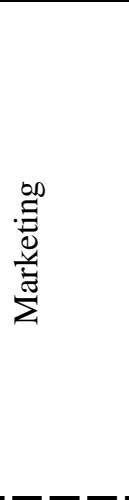 } & $\begin{array}{l}\text { There is no diversity } \\
\text { in marketing } \\
\text { programs. }\end{array}$ & $\begin{array}{l}\text { The lack of } \\
\text { involvement in } \\
\text { global markets. }\end{array}$ & $\begin{array}{l}\text { Weak marketing } \\
\text { management system. }\end{array}$ & $\begin{array}{l}\text { The inability of local } \\
\text { markets to compete. }\end{array}$ \\
\hline & $\begin{array}{l}\text { Government } \\
\text { launched a huge } \\
\text { promotional } \\
\text { campaign "Come } \\
\text { shooting in Kenya } \\
\text { with your camera" } \\
\text { focusing on natural } \\
\text { and } \\
\text { resources. }\end{array}$ & $\begin{array}{l}\text { An idea of 'Wild } \\
\text { Jordan' by the RSCN } \\
\text { for developing and } \\
\text { marketing Ecotourism } \\
\text { products. }\end{array}$ & $\begin{array}{l}\text { Establish and run the } \\
\text { monitoring and } \\
\text { evaluation system for } \\
\text { the project through the } \\
\text { provision of goods, } \\
\text { services and training. }\end{array}$ & $\begin{array}{l}\text { Setting up an Advisory } \\
\text { Board of Ecotourism } \\
\text { Industry and Trade } \\
\text { integrating natural } \\
\text { destinations } \\
\text { development and the } \\
\text { promoting the private } \\
\text { sector. }\end{array}$ \\
\hline 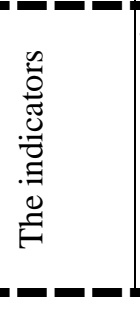 & $\begin{array}{l}\text { Creation/developmen } \\
\text { t of a market niche for } \\
\text { (new) } \\
\text { services/goods. }\end{array}$ & $\begin{array}{l}\text { - Increase investment } \\
\text { volume. } \\
\text { - Support/ development } \\
\text { of other related } \\
\text { economic sector } \\
\text { (handicrafts, etc.). }\end{array}$ & $\begin{array}{l}\text { - Increase the national } \\
\text { income. } \\
\text { - Mechanisms for } \\
\text { financing sustainable } \\
\text { activities. } \\
\text { - Increase employment } \\
\text { opportunities. }\end{array}$ & $\begin{array}{l}\text { - Improve } \\
\text { management } \\
\text { techniques and use } \\
\text { innovative } \\
\text { technologies. }\end{array}$ \\
\hline \multirow{2}{*}{ 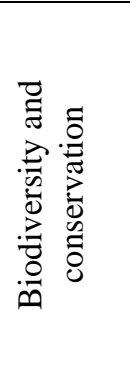 } & $\begin{array}{lr}\text { The } & \text { lack } \\
\text { conservation } & \text { and } \\
\text { management } & \text { of } \\
\text { natural sites, } & \\
\end{array}$ & $\begin{array}{l}\text { Managing the protected } \\
\text { areas as an isolated and } \\
\text { fenced region, with } \\
\text { security guarded. }\end{array}$ & & $\begin{array}{l}\text { The negative impacts } \\
\text { of improper land uses } \\
\text { on the environment and } \\
\text { natural sites. }\end{array}$ \\
\hline & $\begin{array}{ll}\text { Establishing } & \\
\text { department } & \text { of } \\
\text { Wildlife } & \\
\text { Conservation } & \text { and } \\
\text { Management. } & \end{array}$ & $\begin{array}{lr}\text { Constructing } & \text { a } \\
\text { comprehensive } & \text { legal } \\
\text { framework } & \text { for } \\
\text { ecological } & \\
\text { management. } & \end{array}$ & & $\begin{array}{l}\text { Suggesting land uses of } \\
\text { CBE and move the } \\
\text { negative uses outside } \\
\text { of the natural areas. }\end{array}$ \\
\hline 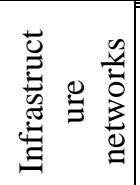 & & & & $\begin{array}{l}\text { The negative } \\
\text { environmental impacts } \\
\text { by the waste-water and } \\
\text { sewage. }\end{array}$ \\
\hline
\end{tabular}




\begin{tabular}{|c|c|c|c|c|}
\hline & & & & $\begin{array}{l}\text { Construction of the } \\
\text { wastewater treatment } \\
\text { plant and sewage } \\
\text { station. }\end{array}$ \\
\hline \multirow{2}{*}{ 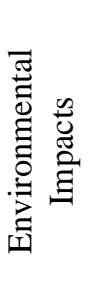 } & $\begin{array}{l}\text { The over-visitation } \\
\text { and mismanagement. }\end{array}$ & & & \\
\hline & $\begin{array}{lr}\text { Regulating } & \text { the } \\
\text { tourists flow } & \text { and } \\
\text { increasing } & \text { their } \\
\text { awareness. } & \end{array}$ & & & \\
\hline 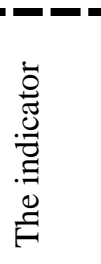 & $\begin{array}{l}\text { - Environmental } \\
\text { management } \\
\text { systems. } \\
\text { - Environmental } \\
\text { impact raising } \\
\text { awareness action. }\end{array}$ & $\begin{array}{l}\text { - Controlling use } \\
\text { intensity. }\end{array}$ & & $\begin{array}{l}\text { - Biodiversity and/or } \\
\text { species conservation } \\
\text { /restoration. } \\
\text { - Pollution and waste } \\
\text { reduction. }\end{array}$ \\
\hline & $\begin{array}{l}\text { The lack of } \\
\text { communication } \\
\text { among all relevant } \\
\text { decision makers. }\end{array}$ & $\begin{array}{l}\text { The little } \\
\text { understanding of the } \\
\text { concept of ecotourism } \\
\text { by the officials. }\end{array}$ & $\begin{array}{l}\text { The need to better } \\
\text { coordination between } \\
\text { stakeholders and local } \\
\text { community. }\end{array}$ & $\begin{array}{l}\text { CBE } \text { initiatives played } \\
\text { a marginal role } \\
\text { compared to the other } \\
\text { tourism schemes. }\end{array}$ \\
\hline 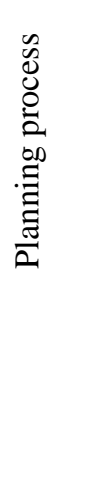 & $\begin{array}{l}\text { There is an Annual } \\
\text { general Meeting } \\
\text { (AGM) and elect a } \\
\text { Management Board } \\
\text { which takes up the } \\
\text { role of an Executive } \\
\text { Committee mandated } \\
\text { with the task of } \\
\text { providing overall } \\
\text { strategic guidance } \\
\text { including approving } \\
\text { plans and budgets. }\end{array}$ & $\begin{array}{l}\text { Supporting the existing } \\
\text { environmental and } \\
\text { planning institutions } \\
\text { for officials training. }\end{array}$ & $\begin{array}{l}\text { Strategic framework for } \\
\text { the management of the } \\
\text { protected areas. } \\
\text { The committees } \\
\text { comprise all } \\
\text { stakeholders for } \\
\text { exchange } \\
\text { information the } \\
\text { consultation around the } \\
\text { sites. }\end{array}$ & $\begin{array}{l}\text { An action plan aiming } \\
\text { to achieve the growth } \\
\text { and improvement of } \\
\text { the Ecotourism through } \\
\text { marketing, } \\
\text { infrastructure building } \\
\text { and human resource } \\
\text { development. }\end{array}$ \\
\hline 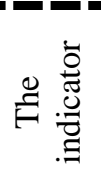 & $\begin{array}{l}\text { - Organize and } \\
\text { manage the annual } \\
\text { meetings. }\end{array}$ & $\begin{array}{l}\text { - Increase } \\
\text { awareness of the } \\
\text { stakeholders. }\end{array}$ & $\begin{array}{lr}\text { - Develop } & \text { strategic } \\
\text { framework } & \text { for } \\
\text { ecotourism } & \text { planning } \\
\text { process. } & \end{array}$ & $\begin{array}{l}\text { - Having a vision for } \\
\text { ecotourism } \\
\text { development. }\end{array}$ \\
\hline
\end{tabular}

\section{THE CORE INDICATORS OF SUCCESSFUL CBE STRATEGIES}

Based on the above analysis of the four case studies, the researcher concluded many indicators (as shown in Table.2). These indicators are going to be used to measure the success of each CBE strategy and explain their impacts on the environment, economy, management policy, and on the community. Through these strategies, the research has divided the indications into four groups: social/cultural, environmental, economic and political indicators. By monitoring these indicators, one will assess whether or not the general objectives for the ecotourism strategy are being met. 
Table (2) The Indicators of CBE Strategies, based on the author

\begin{tabular}{|c|c|c|}
\hline \multicolumn{2}{|c|}{ Indicators } & Specific measures \\
\hline \multirow{7}{*}{ 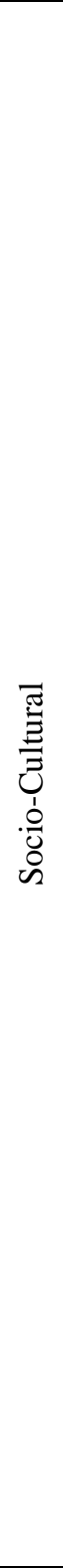 } & $\begin{array}{c}\text { Local } \\
\text { satisfaction } \\
\text { with CBE }\end{array}$ & $\begin{array}{l}\text { Number of Local community complaints. } \\
\text { Percentage of Wellbeing of Host Communities. }\end{array}$ \\
\hline & $\begin{array}{l}\text { Effects of } \\
\text { ecotourism } \\
\text { on } \\
\text { communities }\end{array}$ & $\begin{array}{l}\text { Existence of a community ecotourism plan. } \\
\text { Percentage of who believe that ecotourism has helped bring new services or } \\
\text { infrastructure. } \\
* \text { Number of voluntaries work among local residents. }\end{array}$ \\
\hline & $\begin{array}{c}\text { Community } \\
\text { decision } \\
\text { making }\end{array}$ & $\begin{array}{l}\text { Level of awareness of local values (\% aware, \%supporting). } \\
\% \text { women/men involved directly and indirectly in ecotourism planning and projects. } \\
\text { Frequency of community meetings and attendance rates }(\% \text { of eligible who } \\
\text { participate). } \\
\text { Availability of procedures for public and stakeholders involved to suggest changes } \\
\text { in decisions or policies. }\end{array}$ \\
\hline & $\begin{array}{l}\text { Education } \\
\text { and training }\end{array}$ & $\begin{array}{l}\text { Degree of local knowledge and skills in ecotourism } \\
\text { Number of NGO-s involved in ecotourism. } \\
\text { Number of local programs / schools for training in ecotourism. } \\
\text { Number (\%) participating in community traditional crafts, skills, customs. }\end{array}$ \\
\hline & $\begin{array}{l}\text { Community } \\
\text { benefits }\end{array}$ & $\begin{array}{l}\text { Number of enterprises in the area of recreation and amusements meant to be used by } \\
\text { both local community and Eco-tourists. } \\
\text { Number of ecotourism-oriented enterprises of handicrafts, jewelry or textiles. } \\
\text { Women/men as a \% of all ecotourism employment. }\end{array}$ \\
\hline & Culture & $\begin{array}{l}\text { Increase/decrease in cultural activities or traditional events. } \\
\text { Local traditions, handicraft, folklore and traditional. } \\
\text { Lifestyle conserved and enhanced. } \\
\text { Number or } \% \text { of residents continuing with local dress, customs, language, music, } \\
\text { cuisine, religion and cultural practices. }\end{array}$ \\
\hline & $\begin{array}{c}\text { Tourist } \\
\text { Satisfaction }\end{array}$ & $\begin{array}{l}\text { Increased income from Eco-tourists for natural and environmental Management. } \\
\text { Cof return Eco-tourists \& length of stay. } \\
\text { Changes in average price paid per room. } \\
\text { Needs, recommendations and interests. } \\
\text { Distance to nearest facilities (Km) (as hospital, restaurants, and hotels). } \\
\text { Existence of access program including e.g., airports, bus stations, sidewalks, public } \\
\text { Ratings by guididiebooks. } \\
\text { Existence of a contingency sites. } \\
\text { event of incidents. }\end{array}$ \\
\hline \multirow[b]{2}{*}{ 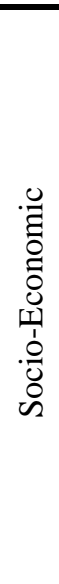 } & $\begin{array}{l}\text { Increased } \\
\text { foreign } \\
\text { exchange } \\
\text { earnings }\end{array}$ & $\begin{array}{l}\text { \% of community income comes from Ecotourism. } \\
\text { Medium, small and micro-enterprises developed. } \\
\text { Eumber of Ecotourism companies. } \\
\text { Occupancy rates for accommodation by month. }\end{array}$ \\
\hline & Employment & $\begin{array}{l}\text { Number of locals (and ratio of men to women) employed in tourism. } \\
\text { The size of the average salary in the community. } \\
\text { Percentage of jobs that are full time, full year. } \\
\text { Local unemployment rate in off-season. } \\
\text { Employee satisfaction; Ability to influence change/improvements in business } \\
\text { processes. } \\
\text { Labor imported (from outside region, from other countries). } \\
\text { Eco-tourist dissatisfaction. }\end{array}$ \\
\hline
\end{tabular}




\begin{tabular}{|c|c|c|}
\hline & $\begin{array}{c}\text { Poverty } \\
\text { alleviation }\end{array}$ & $\begin{array}{l}\text { Annual total income generated by the community. } \\
\text { \% indigenous people employed directly by ecotourism. } \\
\text { Number of ecotourism-related MSMEs operating in the community. } \\
\text { Incentives for MSMEs. } \\
\text { Capacity building for establishing and improving the MSMEs: number of } \\
\text { programs/events, level of participation. } \\
\text { Annual financial contribution by ecotourism to community projects (common fund, } \\
\text { tourism taxes or net value of programs). }\end{array}$ \\
\hline & Marketing & $\begin{array}{l}\text { \% of visitors who seek environmentally friendly and culturally sensitive experiences. } \\
\% \text { of establishments and operators marketing sustainable, sensitive or green } \\
\text { products. } \\
\text { \% of certified businesses that include reference (e.g. logo) of the certification system } \\
\text { in their promotional material. } \\
\text { Volume of marketing products divided by type (brochures, advertisements in } \\
\text { different media, posters, websites, etc). } \\
\text { Level of representation/contact (number of fairs, exhibits, journalists' trips, } \\
\text { familiarization trips for tour operators). } \\
\% \text { Eco-tourists who agree that the reality matched what was advertised. } \\
\text { \% clients who are satisfied with their experience. }\end{array}$ \\
\hline \multirow{4}{*}{ 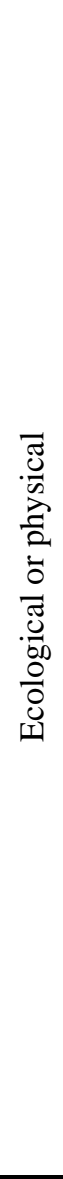 } & $\begin{array}{l}\text { Biodiversity } \\
\quad \text { and } \\
\text { conservation }\end{array}$ & $\begin{array}{l}\text { Number of Eco-tourists per square meter of the site. } \\
\text { \% of total capacity used. } \\
\text { Extent of protected area(s) - square km (classified by level of protection). } \\
\text { Ecotourism contribution to protection and restoration. } \\
\text { Encrease in abundance and diversity of flora and fauna. }\end{array}$ \\
\hline & $\begin{array}{l}\text { Infrastructur } \\
\text { e networks }\end{array}$ & $\begin{array}{l}\text { \% existing roads, roadside facilities, vehicles. } \\
\text { Density of public transport (route kms per km 2). } \\
\text { New lines developed for ecotourism; existing lines exploited to generate new } \\
\text { categories of travelers. } \\
\text { Number of direct flights, number of cities served by direct flights (and \% passengers } \\
\text { arriving without stops). } \\
\text { Coverage of mobile phones and WIFI broadband availability extended. } \\
\text { Number of transport accidents and fatalities (land, air and maritime). }\end{array}$ \\
\hline & $\begin{array}{l}\text { Visual } \\
\text { Impacts of } \\
\text { ecotourism } \\
\text { Facilities }\end{array}$ & $\begin{array}{l}\text { Height of buildings (average and maximum). } \\
\text { Density of buildings per hectare. } \\
\text { Shapes of buildings. } \\
\text { Existence of aesthetic considerations in planning approval process. } \\
\text { \% olor and Texture (\% matching or coordinating with vernacular). } \\
\% \text { of site covered by indigenous plants. }\end{array}$ \\
\hline & $\begin{array}{c}\text { Environment } \\
\text { al Impacts }\end{array}$ & $\begin{array}{l}\text { \% of treated sewage recycled. } \\
\% \text { of destination area (especially in urban sites) covered by solid waste collection } \\
\text { services. } \\
\text { Percentage of Ecotourism establishments covered by waste collection programs. } \\
\text { Image of cleanliness of destination. } \\
\text { Measuring Noise Levels, Perception of Noise. } \\
\% \text { of energy consumption from renewable resources (at destinations, } \\
\text { establishments). }\end{array}$ \\
\hline 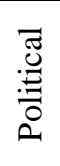 & $\begin{array}{l}\text { Planning } \\
\text { process }\end{array}$ & $\begin{array}{l}\text { Existence of organizes plan for Eco-tourist destination region (including Ecotourism } \\
\text { component). } \\
\text { Developing management skills (standard regulations, systematic management). } \\
\text { Integrated cooperation (government, operators and community). }\end{array}$ \\
\hline
\end{tabular}

As a result of the evaluation, the indicators of each strategy vary in line with the priority of each country, as follows: 
- Political indicators: Development and management of CBE require conducive environment, which can facilitate its implementation from paper to the ground and make CBE management applicable. Taken together, the information gathered indicates the extent of political commitment to CBE development and covers most of the legal and institutional frameworks. This requires skilled manpower, and good administrative environment right from the planning level to its implementation. Furthermore, developing the required techniques to stay up the safety and security of Eco-tourists, and ensure the access to the natural and cultural sites. For example Tunisia, in the aftermath of the revolution, many issues previously not highlighted by the national and international institutions have been brought to new light and importance in the tourism development agenda. With support of the Critical Ecosystem Partnership Fund (CEPF) through its investment in the Mediterranean Basin biodiversity hotspot, and nongovernment organizations such as the Association Les Amis des Oiseaux (AAO), Tunisia has developed CBE activities for the conservation of key biodiversity areas in northern Tunisia and supporting local communities to manage the natural areas there.

- Socio-Economic indicators: Having an applicable institutional framework in sharing the benefits, raising the quality of services, as well as, promoting and increasing the local product to the worldwide markets assure the success of CBE development process. It can be only done through diversifying the livelihood opportunities for local people and supporting them financially and legally. The socio-economic indicators help to discover if CBE development can actually meet local needs or contribute to a locally defined vision of development or not. For example, the Jordanian Government has demonstrated strong commitment to encourage the growth of CBE. To this end, it has committed in allocating $4 \%$ of national tourism receipts for international marketing, and the development of both products and human resources. The National Tourism Strategy from 2004 to 2010 has proven to be extremely successful, with the goal of doubling the contribution of tourism to GDP having been achieved before the end of the project. Resulting, ecotourism directly supporting around 160.000 families throughout Jordan. Through income-generating projects of ecotourism, communities living around nature reserves earned 2.3 million USD in 2012.

- Socio-cultural indicators: the local community is the most important partner in the CBE development process, their involvement in each level of the process and taking their opinions into account ensures its success and sustainability. The participation of the local people in providing ecotourism services is the outcome of the project as well as constructive contribution by local institutions and international NGOs. This can be done involving the local communities in the meetings of CBE process, as well as developing and training human resources, and increase their awareness towards the natural and cultural resources. For instance, The Government of India has decided to involve citizens in environmental management. As a part of this campaign, people were invited to the Wildlife Sanctuaries and National Parks where they can cohabit with the other living beings and learn about the environment everywhere in India. Also, a management plan 
for each ecotourism area was prepared by professional landscape architects and urban planners, in consultation with the local community as well as others directly concerned. Furthermore, integrated planning was adopted to avoid sectoral and local community conflict.

- Ecological or physical indicators: These indicators refer to the maintenance of the healthy ecosystem of natural sites. Through understanding the environmental implications of illplanning, setting the essential laws for protecting the natural and cultural areas, determination of carrying capacity which should be pre-requisite for the development of any ecotourism destination. As well as, design a good network of important tourist sites and provide a suitable infrastructure. For example in Kenya, CBE activities emanate from the need to conserve the natural resources for the purposes of local community wellbeing. When $\mathrm{CBE}$ was analyzed, it emerged that there were some problems in dealing with natural resources. Now, CBE is described as an important strategy in natural resource utilization and management in Kenya.

\section{CONCLUSION}

Many developing countries often adopt the top down approach in their ecotourism development plans. Since the emergence of CBE as a form of ecotourism that is very necessary to empower local communities and its economy, protect the environment and natural sites as well, many developing countries decided to formulate and apply its strategies. This paper examined the CBE strategies of four developing countries and measures their success by distinctive major indicators; these countries are Republic of Kenya, Tunisia, Jordan, and India. As an example, Kenya's strategy has succeeded in protecting the natural beauty and distinctive wildlife resources; Tunisia's strategy has created great progress on political stability likewise. As for Jordan, the strategic objective was the key to expand the local and global markets. In India, supporting its community and raising their standards of living were the foremost aims of their strategy.

For planning a successful CBE development strategy, there are many indicators which ought to concern with: -Good CBE plans and policies should be complemented by effective legislation and policy for each cluster of stakeholders, to ensure that they are doing not impinge negatively on local communities or surrounding environment. -A fair share within the benefits of ecotourism between all partners significantly the locals. -A training program to make community capacity to develop their confidence to discuss and review their visions within the planning process, and run a successful CBE venture. -A court management and continuous evaluation of the ultimate outcomes of each stage of the process, to figure out whether or not the factors succeeded or unsuccessful in implementing the objectives and check out to develop it.

As a continuation of research throughout this field within the future, Egypt as a developing country must formulate an applicable CBE strategy, to collect all relevant stakeholders' particularly local community with none exclusion, and exchange their information and opinions well at each step of the planning process. Moreover, stakeholders themselves should 
be trained to understand additional regarding the key principles of CBE development planning and to be aware of past mistakes and guarantees that haven't been enforced. Also, to understand how evaluating the implementation of this strategy.

\section{REFERENCES}

(MEET), M.-T. (2014). A survey of ecotourism best practices in the world. Italy: Stefania Mauro, Luca Santarossa, Paolo Pigliacelli, FEDERPARCHI - Europarc.

Baken, R. (2010). Some reflections on tourism and tourism policy in India. Indian Institute of Management Bangalore, Bannerghatta Road, Bangalore, India.

CEPF, T. (2016). DEVELOPING ECOTOURISM TO CONSERVE BIODIVERSITY IN TUNISIA. http://www.cepf.net/ourstories/Features/Pages/Developing-Ecotourism-to-ConserveBiodiversity-in-Tunisia.aspx.

The green economy in Tunisia,. (2014). an implementation tool of the new sustainable (2014-2020).

Asker, S. B. (2010). Effective Community Based Tourism: A Best Practice Manual. Sustainable Tourism Cooperative Research Centre.

Bhanoo, S. (2015). Community Participation in Conservation of Great Himalayan National Park, India. Notion Press; 1 edition.

CISS \& EDG. (2012). Ecotourism for sustainable development in the New Valley Governorate. Egypt: CISS \& Environmental Design Group.

EEAA \& MSEA. (2010). Egypt State of the Environment Report 2010. Egypt: EEAA \& MSEA.

EEAA. (2017). EEAA Institutional Framework. Retrieved 3 10, 2017, from Ministry of Environment Egyptian Environmental Affairs Agency: http://www.eeaa.gov.eg/en-us/aboutus.aspx

EK, E. (2016). strategic Plan 2016-2020. https://issuu.com/brandeffectseastafrica/docs/strategic_plan_2016-2020 .

El-Harami, J. ( 2014). The Diversity of Ecology and Nature Reserves as an Ecotourism Attraction in Jordan. Al-Zaytooneh University of Jordan, Amman, Jordan, by EDP Sciences,.

ESOK. (2004). newsletter of the ecotourism society of Kenya . Judy Kepher - Gona.

Gopal, K. (2012). ECOTOURISM IN INDIA. FUTURARC.

Hegazy, I. (2010). Strategic environmental assessment and urban planning system in Egypt,. PhD, Bournemouth University.

Ibrahim , M. (2011). Protected Areas in Egypt. Egypt: Second edn, EEAA, MSEA.

IOM, I. o. (2012). Education and Training for Egyptian youth in Fayoum Governorate: Activities to promote Regular Migration and Positive Alternatives. Egypt: IOM.

Katia lankova, A. H. (2016). Indigenous People and Economic Development. Routledge.

Loughlin, J. \&. (2012). Do we Need To Rethink Egypt's Territorial Governance and Planning for Economic Development? Egypt: UN-Habitat, Ministry of Housing \& Utilities and Urban Development and Ministry of Local Development.

MPIC. (2012). Strategic Framework for Economic and Social Development plan Until year 2022. Egypt: Ministry of Planning and International Cooperation.

NCS. (2006). PROTECTED AREAS OF EGYPT: TOWARDS THE FUTURE. EGYPT: Ministry of State for Environmental Affairs, Egyptian Environmental Affairs Agency, Nature Conservation Sector.

Ngunyi, R. (2009). Ecotourism and Sustainable Development in Kenya, Doctorate in tourism management, School of business, Department of Hotel and Tourism Management, Sun $Y$ at Sen University. 
OECD. (2010). Tourism Trends and Policies 2010. Paris: Organization for Economic Cooperation and Development.

RSCN, t. (2012). the report Jordan. oxford business group, https://books.google.com.eg/books?id=8iKNxQ2GvCcC\&printsec=frontcover\&hl=ar\#v=onepag $e \& q \& f=f a l s e$.

Salazar, N. (2012). Community-based cultural tourism: Issues, threats and opportunities. Journal of Sustainable Tourism, 10.

Shalaby, M. (2012). Realities of the Sustainable Planning Process of Egyptian Industrial Zones: The case of the Industrial Parks. UK: PhD, Cardiff University.

Tamagn, W. (2015). Challenges of Implementing Community Based Ecotourism. LAP Lambert Academic Publishing.

TDA. (2016). Ecotourism in Dahsur. Retrieved 3 20, 2017, from tourism development authority: http://www.tda.gov.eg/Dahshour/IntroEn.aspx

TDA, T. (2008). NATIONAL SUSTAINABLE, for the year 2020. Egypt: MINISTRY OF TOURISM.

Telfer and Sharpley. (2008). Tourism and Development in the Developing World. London: Routledge. UNEP, WTO. (2005). making tourism more sustainable, a guide for policy makers. united nations enviromentl programme and world tourism organization.

UNWTO, W. (2013). UNWTO Annual Report 2012. Madrid, Spain: by the World Tourism Organization (UNWTO).

WTO. (2004). Indicators of Sustainable Development for Tourism Destinations. Madrid, Spain: World Tourism Organization. 